Journal of

$$
\begin{aligned}
& \text { Entreprenuership and } \\
& \text { Project Management } \\
& \text { (JEPM) }
\end{aligned}
$$

FACTORS AFFECTING ADOPTION OF DONOR FUNDED ICT PROJECTS IN THE PUBLIC SECTOR IN KENYA

Alex King’ori Ndegwa, Dr. Peter Kiriri and Dr. George Achoki

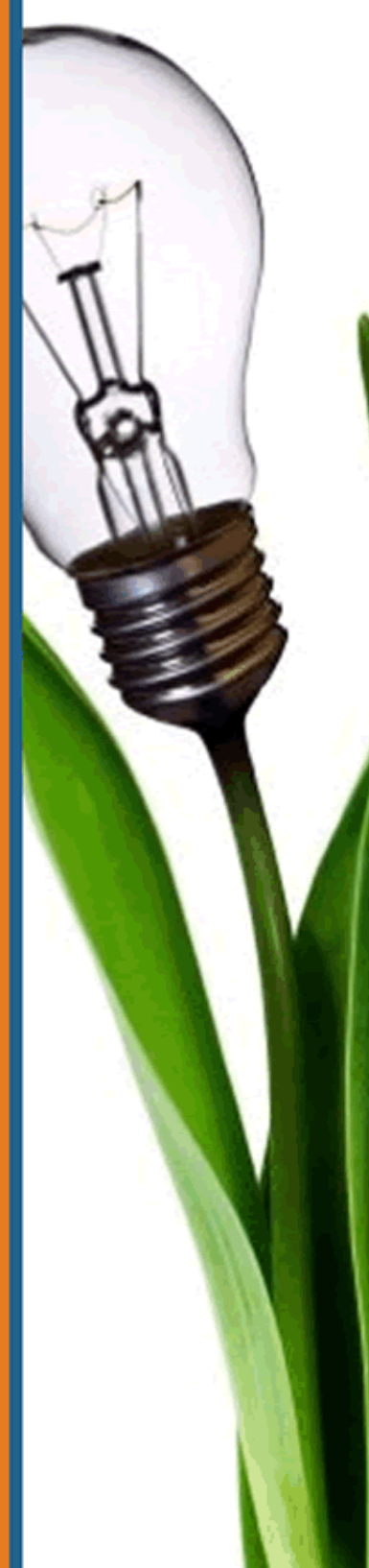

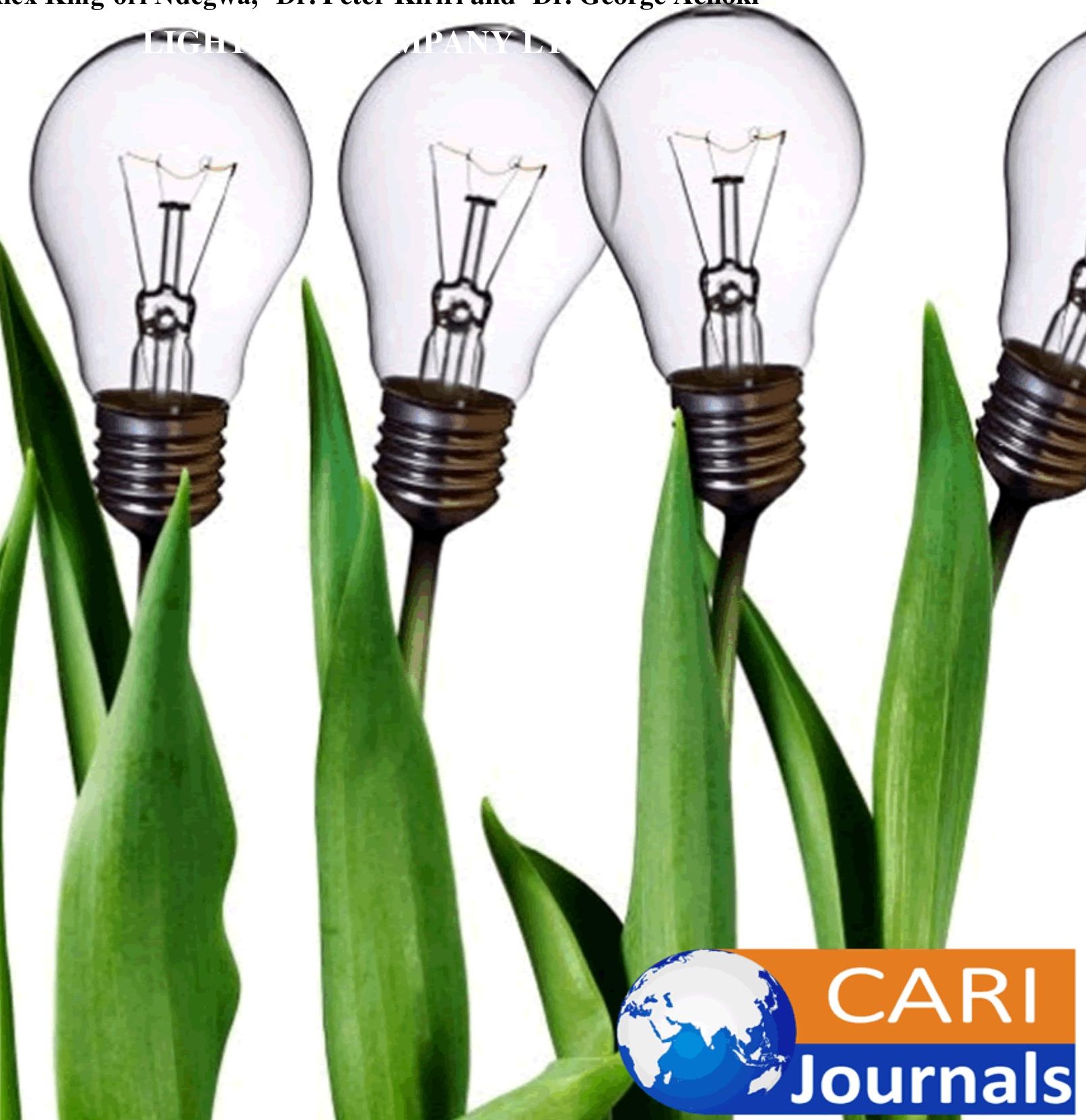




\title{
FACTORS AFFECTING ADOPTION OF DONOR FUNDED ICT PROJECTS IN THE PUBLIC SECTOR IN KENYA
}

\author{
1* Alex King'ori Ndegwa \\ Post graduate student: United States International University \\ *Corresponding Author's Email: alexkingori@gmail.com \\ ${ }^{2}$ Dr. Peter Kiriri \\ United States International University \\ ${ }^{3}$ Dr. George Achoki \\ United States International University
}

\begin{abstract}
Purpose: The purpose of this study was to establish the factors affecting adoption of donor funded ICT projects in the public sector.

Methodology: The research was carried out through a descriptive survey research design. The sampling frame of this survey was a list of state owned enterprises in Nairobi County. The study targeted a population of all the 205 state owned enterprises in Kenya out of which 67 are located in Nairobi County.

Results: The relationship between technological factor and adoption of donor funded ICT projects was positive and significant. The findings imply that technological factor has significant effect on adoption of donor funded ICT projects. The relationship between Infrastructural factor and adoption of donor funded ICT projects was positive and significant. The findings imply that Infrastructural factor has significant effect on adoption of donor funded ICT projects.

Unique contribution to theory, practice and policy: It was recommended that government should consider implementing a robust public sector policy that aims at enhancing ICT use, the development of donor funded ICT project and making ICT hardware and software accessible and affordable to majority of individual and firms. It is recommended that the government considers improving the adoption of donor funded ICT project in public sectors through training in school and institution of higher learning. The management of public sectors should also continue to adopt new forms of technology that would assist in improving donor funded ICT projects. Management of companies should appreciate that in adoption of donor funded ICT project there are benefits of first adapters or first movers.
\end{abstract}

Keywords: technological factors, Culture, Infrastructural factors, ICT project, Public sectors 
Journal of Entrepreneurship and Project Management

ISSN 2520 - 9116 (Online)

Vol. 2, Issue 1 No. 1, pp 1 - 19, 2016

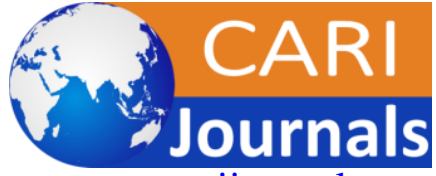

WwW.carijournals.org

\subsection{INTRODUCTION}

Throughout the whole world, there has been a paradigm shift where governments and other independent policy/law makers have realized the importance of e-government as a strong tool for responsive governance. Traditionally, many governments have been using paper-and-file approaches in managing their businesses and this has proved disadvantageous in as far as accountability is concerned (Mehrtens et al., 2001).

In support of government informatics, Tapscott (1995) argues that ICT causes a "paradigm shift" introducing "the age of network intelligence", reinventing businesses, governments and individuals. Ndou (2004) quoting Kaufman (1977) observes, "the traditional bureaucratic paradigm, characterized by internal productive efficiency, functional rationality, departmentalization, hierarchical control and rule-based management is being replaced by competitive, knowledge based requirements, such as: flexibility, network organization, vertical/horizontal integration, innovative entrepreneurship, organizational learning, speed up in service delivery, and a customer driven strategy, which emphasize coordinated network building, external collaboration and customer services" all of which are supported by ICT.

According to Kaul and Odedra (1991) governments around the world have been engaged in the process of implementing a wide range of (ICT) applications. Countries have been classified by the United Nations according to their Computer Industry Development Potential (CIPD) as advanced or less developed Mgaya (1999). Advanced include, for example, the United States, Canada, West European countries and Japan; less developed include for example Argentina, Brazil, India, Mexico, Kenya and Bulgaria. For all countries, use of ICTs for government reinvention is increasing not only in investment but also in terms of visibility with a number of high-profile initiatives having been launched during the 1990s. According to Heeks and Davies (2000), this reinvention has taken place especially in the advanced countries. Western countries are convinced that the information society will result in economic and social benefits (Audenhove, 2000). Heeks and Davies (2000) quote that organization for Economic Cooperation and Development, notes that information infrastructures are expected to stimulate economic growth, increase productivity, create jobs, and improve on the quality of life.

Over the last five years, the Kenyan government has initiated some capital investment towards set up and installation of ICT infrastructure. Funding for these investments is achieved through partnerships between the government and development partners. The foreign funding component constitutes the largest percentage of this investment in terms of technology. The government contribution is usually in the form of technical and support staff and facilities including buildings. So far, the Government Information Technology Investment and Management Framework are connecting all ministries to the Internet under the Executive Network (Limo, 2003).

The government is also connecting the ministries to run integrated information systems for example the Integrated Financial Management Information System (IFMIS) and the Integrated Personnel and Pensions Database (IPPD). While developing countries may have similar characteristics, the Kenyan context presents various challenges that affect the successful implementation of ICT projects. Characteristics that define Kenyan ICT environment: Most ICT projects are initially donor funded; some donations are made without prior consultation or 
carrying out a needs analysis by the recipient organization and operational/running costs are met by the government; Funding (capital and human resource requirements) ends with the project phase; The budgets for ICT are inadequate but rising; a lack of ICT policies and master plans to guide investment. To the extent that, with a number donors funding ICT, there have been multiple investments for the same product due to lack of coordination; a focus on ICT applications that support traditional administrative and functional transactions rather than on effective information processing and distribution within and without government departments and unstable ICT resources.

\subsection{Problem Statement}

In Kenya, most ICT projects are initially donor funded; some donations are made without prior consultation or carrying out a needs analysis by the recipient organization and operational/running costs are met by the government; Funding (capital and human resource requirements) ends with the project phase; The budgets for ICT are inadequate but rising; a lack of ICT policies and master plans to guide investment. To the extent that, with a number donors funding ICT, there have been multiple investments for the same product due to lack of coordination; a focus on ICT applications that support traditional administrative and functional transactions rather than on effective information processing and distribution within and without government departments and unstable ICT resources. This indicates that there is a problem in coordinating and facilitating the adoption of donor funded ICT projects in Kenya.

Studies on the area of E-government adoption are abundant. For instance Heeks (2003) investigated the success of government ICT projects and partition e-government success in three different categories: Total failure; Partial failure; and Success. Ndou (2004) investigated Opportunities and challenges of E-Government for developing countries and concluded that developing countries stand to gain. However, none of the studies focused on factors affecting adoption of donor funded ICT projects in the public sector in Kenya. This is the research gap that this study sought to bridge.

\subsection{Research Objectives}

i. What are the technological factors that influence the adoption of donor funded ICT project in public sectors?

ii. What is the influence of culture on the adoption of donor funded ICT project in public sectors?

iii. What are the infrastructural factors that influence the adoption of donor funded ICT project in public sectors?

\subsection{LITERATURE REVIEW}

\subsection{Theoretical Framework: Rogers Diffusion of Innovation theory}

Rogers' (1995) Diffusion of Innovation (DOI) theory is a popular model used in information systems research to explain user adoption of new technologies. Rogers defines diffusion as 'the process by which an innovation is communicated through certain channels over time among the members of a social society' (Rogers, 1995). An innovation is an idea or object that is perceived 
Journal of Entrepreneurship and Project Management

ISSN 2520 - 9116 (Online)

Vol. 2, Issue 1 No. 1, pp 1 - 19, 2016

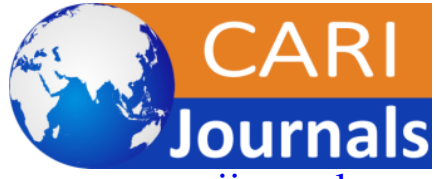

WwW.carijournals.org

to be new (Rogers, 1995). According to DOI, the rate of diffusion is affected by an innovation's relative advantage, complexity, compatibility, trialability and observability.

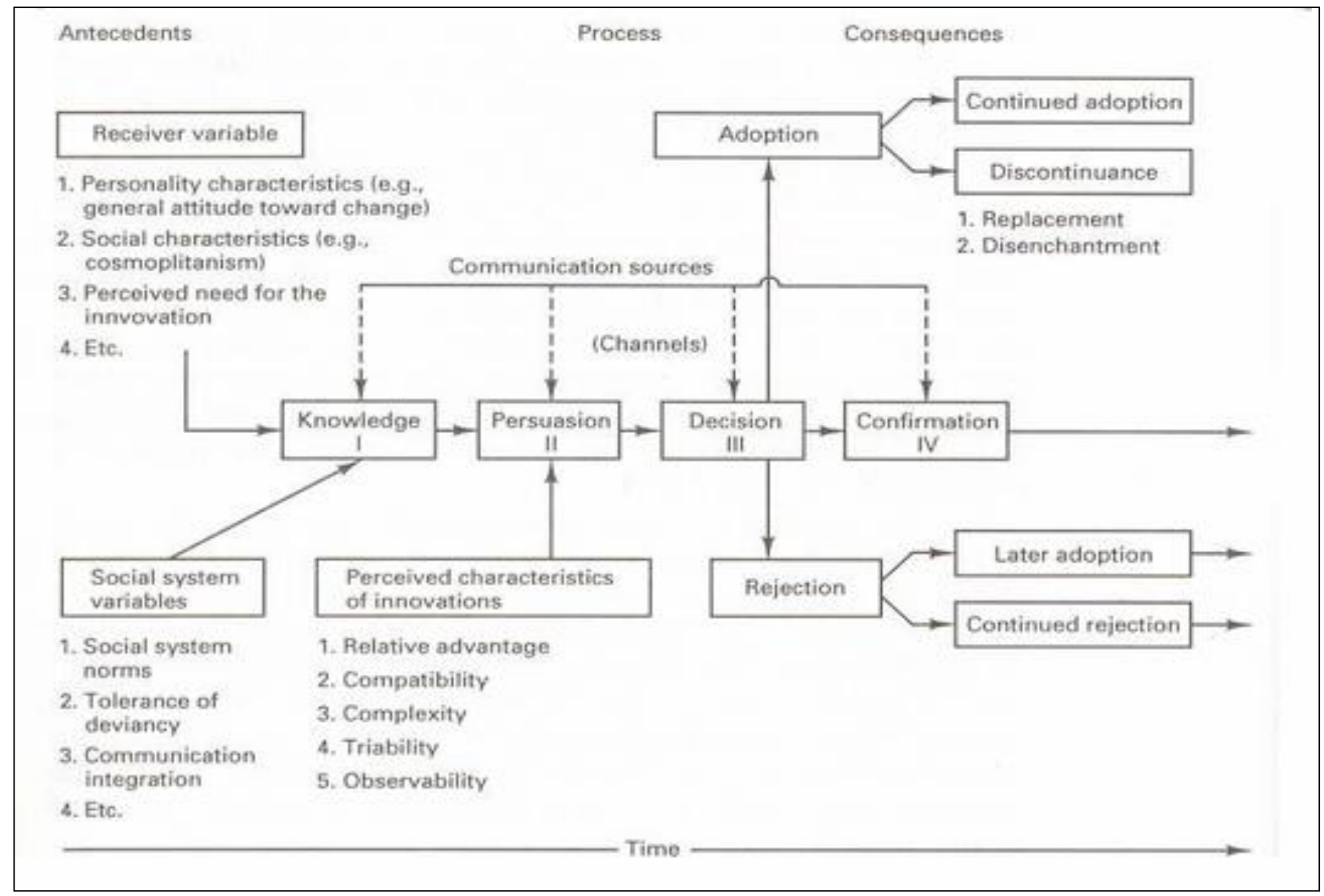

Figure 1: Diffusion of innovation model.

Source: Rogers (1995)

\subsection{Empirical Review}

Cultural factors are the cultural patterns of collective behavior that influence the project (Rozendal, 2002). To explain cultural behavior, we have to compare cultures and search for the aspects in which they are different. To this end, cultural anthropologists have developed variables on which cultures can be different or similar. These are Time orientation, communication, Centralization, Bureaucracy.

Ghalandari (2012) conducted a study on the effect of Performance Expectancy, Effort Expectancy, Social Influence and Facilitating Conditions on Acceptance of E-Banking Services in Iran by focusing on the Moderating Role of Age and Gender. The study concluded that with respect to positive and significant effect of facilitating conditions on using e-banking services, it is recommended that infrastructure e.g. computers and high-speed and affordable internet required in this field is provided to all social classes.

Akturan and Tezcan (2010) investigated the effect of innovation characteristics on mobile banking adoption intention and noted that compatibility is the perception of innovation as being 
consistent with the existing values, past experiences, and needs of potential adopter. It is related with how well the innovation fits into the adopters' existing social structure. When an innovation perceived as compatible, it is perceived as consistent with an individual's life situation. In this study compatible was found as an important innovation characteristic that has a significant effect on adoption intention. When the prospects perceive that using mobile banking is compatible with all aspects of banking, is completely compatible with their current ways of banking and fits well with the way they like to do banking, they tend to adopt.

\subsection{RESEARCH METHODOLOGY}

A descriptive survey research design will be used to assess the factors affecting adoption of donor funded ICT projects in the public sector. The study targeted a population of all the 205 state owned enterprises in Kenya out of which 67 are located in Nairobi County. This comprised the population of the study. The questionnaires were designed based on the research questions and pre-tested to ascertain the suitability of the tool before the actual administration. Pre-testing on five people was done by administering the questionnaire to respondents who were selected purposively. Descriptive statistics such as, mean and frequencies were used to perform data analysis. The mean scores was used to rate the factors in order of their importance. These measures were calculated using Statistical Package for the Social Sciences (SPPS 20.0) software. SPSS tool (Statistical Package for the Social Sciences) which was used to organize and analyze data. This is because it is user friendly and gives all the possible analysis. A qualified statistician helped to analyze the data (Castillo, 2009). The data were presented in form of tables and charts.

\subsection{RESULTS AND DISCUSSIONS}

\subsection{Demographic characteristics}

Results on Figure 1 show that $81 \%$ of the respondents were males while $19 \%$ of the respondents were females. These results are indicative of a male dominated working environment among adoption of donor funded ICT projects in the public sector in Kenya.

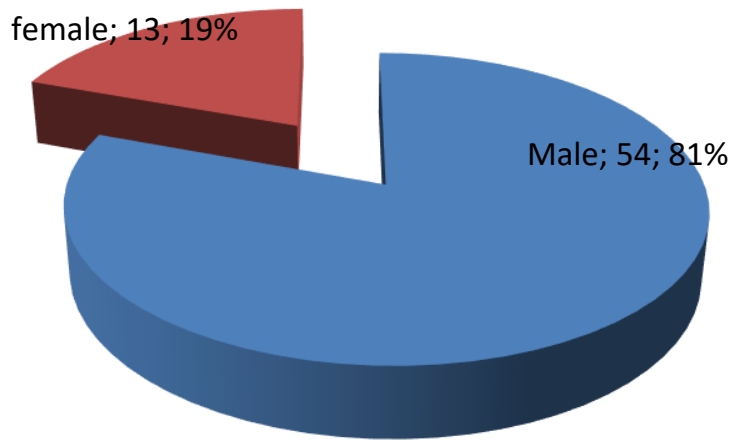

\section{Figure 1: Gender}

Based on the results presented on Figure 2, majority $72 \%$ of the respondents were managements in the adoption of donor funded ICT projects in the public sector in Kenya while $28 \%$ of the respondents were employee. 
Journal of Entrepreneurship and Project Management

ISSN 2520 - 9116 (Online)

Vol. 2, Issue 1 No. 1, pp 1 - 19, 2016
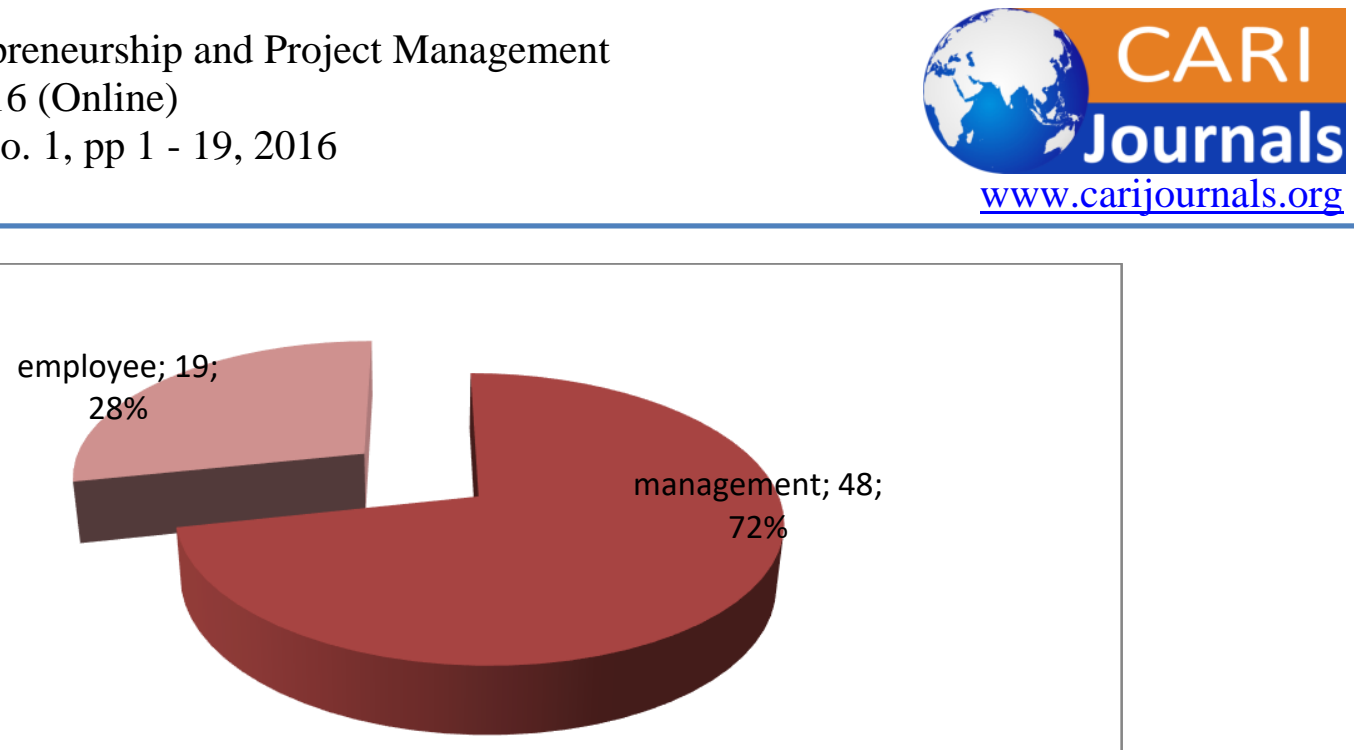

\section{Figure 2: Position in organization}

Based on the results presented on Figure 3 majority (70\%) of the respondents were holding university degrees while the rest $(30 \%)$ were below diploma.

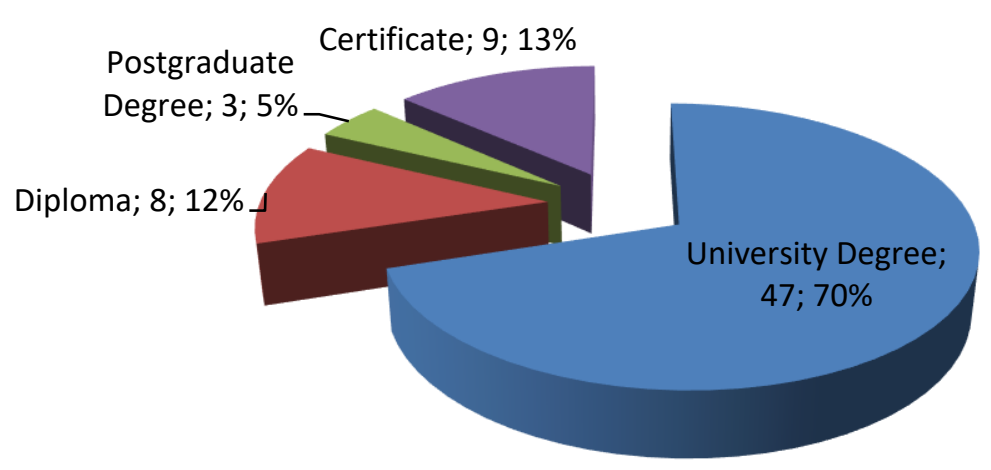

\section{Figure 3: Level of education}

\subsection{Technology factor}

The study sought to determine the factors affecting adoption of donor funded ICT project in public sectors in Kenya. The results were presented as follows.

The respondents were asked if Perceived usefulness is a key factor influencing adoption of donor funded ICT project. A majority $(64.2 \%)$ of the respondents agreed while $9 \%$ of the respondents strongly agreed bringing to a total of $(73.2 \%)$ of those who agreed. Eleven point nine percent $(11.9 \%)$ of the respondents were neutral and $9.0 \%$ disagreed and $6.0 \%$ strongly disagreed. The results are presented in table 1. 
Table 1: Perceived usefulness is a key factor influencing adoption of donor funded ICT project

\begin{tabular}{|c|c|c|}
\hline & Frequency & percent \\
\hline $\begin{array}{ll}\text { Perceived usefulness is a } & \text { strongly disagree } \\
\text { key factor influencing } & \text { disagree } \\
\text { adoption of donor } & \text { neutral } \\
\text { funded ICT project. } & \text { agree } \\
& \text { strongly agree }\end{array}$ & $\begin{array}{l}4 \\
6 \\
8 \\
43 \\
6\end{array}$ & $\begin{array}{l}6.0 \% \\
9.0 \% \\
11.9 \% \\
64.2 \% \\
9.0 \%\end{array}$ \\
\hline
\end{tabular}

The respondents were asked if the Perceived ease of use is a key factor influencing adoption of donor funded ICT project. A majority (49.3\%) agreed while $13.4 \%$ strongly agreed bringing to a total of $(62.7 \%)$ of those who agreed. Twenty five point four percent was neutral and $6 \%$ of the respondents disagreed and $6 \%$ of the respondents strongly disagreed. The results are presented in table 2 .

Table 2: Perceived ease of use is a key factor influencing adoption of donor funded ICT project

\begin{tabular}{llll}
\hline & & Frequency & percent \\
\hline & strongly disagree & 4 & $6.0 \%$ \\
Perceived ease of use is a key Disagree & 4 & $6.0 \%$ \\
factor influencing adoption & of Neutral & 17 & $25.4 \%$ \\
donor funded ICT project. & Agree & 33 & $49.3 \%$ \\
& strongly agree & 9 & $13.4 \%$ \\
\hline
\end{tabular}

The respondents were asked if the Reduction in operational costs is a key factor influencing adoption of donor funded ICT project. A majority (53.7\%) agreed while $20.9 \%$ strongly agreed bringing to a total of (74.6\%) of those who agreed. Ten point four percent were neutral and $11.9 \%$ disagreed and also $3 \%$ of the respondents strongly disagreed. The results are presented in table 3

Table 3: Reduction in operational costs is a key factor influencing adoption of donor funded ICT project

\begin{tabular}{|c|c|c|}
\hline & Frequency & percent \\
\hline $\begin{array}{ll}\text { Reduction in operational costs is a } & \text { Disagree } \\
\text { key factor influencing adoption of } & \text { Neutral } \\
\text { donor funded ICT project. } & \text { Agree } \\
& \text { strongly agree }\end{array}$ & $\begin{array}{l}2 \\
8 \\
7 \\
36 \\
14\end{array}$ & $\begin{array}{l}3.0 \% \\
11.9 \% \\
10.4 \% \\
53.7 \% \\
20.9 \%\end{array}$ \\
\hline
\end{tabular}




\subsubsection{Improvement in revenues is a key factor influencing adoption of donor funded ICT} project.

The respondents were asked if the improvement in revenues is a key factor influencing adoption of donor funded ICT project. Majority (56.7\%) of the respondents agreed while $19.4 \%$ strongly agreed bringing to a total of $(76.1 \%)$ of those who agreed. Eleven point nine percent were neutral and $9 \%$ disagreed and $3 \%$ of the respondents strongly disagreed. The results are presented in table.4.

Table 4: Improvement in revenues is a key factor influencing adoption of donor funded ICT project.

\begin{tabular}{|c|c|c|}
\hline & Frequency & percent \\
\hline $\begin{array}{ll} & \text { strongly disagree } \\
\text { Improvement in revenues is a key } & \text { Disagree } \\
\text { factor influencing adoption of Neutral } \\
\text { donor funded ICT project. } & \text { Agree } \\
& \text { strongly agree }\end{array}$ & $\begin{array}{l}2 \\
6 \\
8 \\
38 \\
13\end{array}$ & $\begin{array}{l}3.0 \% \\
9.0 \% \\
11.9 \% \\
56.7 \% \\
19.4 \%\end{array}$ \\
\hline
\end{tabular}

The respondents were asked if increased customer outreach is a key factor influencing adoption of donor funded ICT project. Majority (44.8\%) agreed while $25.4 \%$ strongly agreed bringing to a total of $(70.2 \%)$ of those who agreed. Thirteen point four percent were neutral and $10.4 \%$ disagreed and $6 \%$ strongly disagreed. The results are presented in table 5.

Table 5: Increased Customer Outreach is a Key Factor Influencing Adoption of Donor Funded ICT Project.

\begin{tabular}{|c|c|c|}
\hline & Frequency & percent \\
\hline \begin{tabular}{ll} 
Increased customer outreach is a & \multicolumn{1}{c}{ strongly disagree } \\
key factor influencing adoption of & Neutral \\
donor funded ICT project. & Agree \\
& strongly agree
\end{tabular} & $\begin{array}{l}4 \\
7 \\
9 \\
30 \\
17\end{array}$ & $\begin{array}{l}6.0 \% \\
10.4 \% \\
13.4 \% \\
44.8 \% \\
25.4 \%\end{array}$ \\
\hline
\end{tabular}

The respondents were asked if Customer satisfaction is a key factor influencing adoption of donor funded ICT project. A majority $46.3 \%$ of the respondents agreed with the statement while $14.9 \%$ strongly agreed bringing to a total of $(61.2 \%)$ of those who agreed. Twenty eight point four percent were neutral and $6.0 \%$ disagreed and $4.5 \%$ strongly disagreed. The results are presented in table .6 . 
Table 6 Customer satisfaction is a key factor influencing adoption of donor funded ICT project

\begin{tabular}{|l|l|l|l|}
\hline & Frequency & percent \\
\hline \multicolumn{2}{|c|}{ strongly disagree } & 3 & $4.5 \%$ \\
Customer satisfaction is a key Disagree & 4 & $6.0 \%$ \\
factor influencing adoption of Neutral & 19 & $28.4 \%$ \\
donor funded ICT project. & Agree & 31 & $46.3 \%$ \\
& strongly agree & 10 & $14.9 \%$ \\
\hline
\end{tabular}

Correlation results in table 7 indicates that the relationship between technological factor and adoption of donor funded ICT projectis positive and significant $(\mathrm{r}=0.795, \mathrm{p}$ value $<0.000)$. The findings imply that technological factor has significant effect on adoption of donor funded ICT project.

Table 7: Correlations

\begin{tabular}{|ll|l|l|}
\hline & & Donor Funded & Technology Factor \\
\hline \multirow{4}{*}{ Donor Funded } & Pearson Correlation & 1 & \\
& Sig. (2-tailed) & & \\
& N & 67 & \\
& Pearson Correlation & .795 & 1 \\
Technology Factor & Sig. (2-tailed) & .000 & \\
& N & 67 & 67 \\
\hline
\end{tabular}

\subsection{Organizational Culture}

The respondents were asked if the organization cultures are focused on the short term, therefore, the organization expects quick results and this has influenced ICT adoption. A majority 55.2\% of the respondents agreed while $13.4 \%$ strongly agreed bringing to a total of $(68.6 \%)$ of those who agreed. Thirteen point four percent were neutral and $13.4 \%$ disagreed and $4.5 \%$ strongly disagreed. The results are presented in table 8

Table 8: The organization cultures is focused on the short term, therefore, the organization expects quick results and this has influenced ICT adoption

\begin{tabular}{|l|c|c|}
\hline & Frequency & percent \\
\hline The organization cultures is strongly disagree & 3 & $4.5 \%$ \\
focused on the short term, Disagree & 9 & $13.4 \%$ \\
therefore, the organization expects Neutral & 9 & $13.4 \%$ \\
quick results and this has Agree & 37 & $55.2 \%$ \\
influenced ICT adoption & 9 & $13.4 \%$ \\
\hline
\end{tabular}

The respondents were asked if the organization culture focuses on long term issues which make it better to perceive the long term benefits of ICT and, therefore, this makes it more favorable in adoption of donor funded ICT. A majority $65.7 \%$ of the respondents agreed while $13.4 \%$ 
strongly agreed bringing to a total of $(79.1 \%)$ of those who agreed. $10.4 \%$ of the respondents were neutral and $7.5 \%$ disagreed and $3 \%$ strongly disagreed. The results are presented in table 9

Table 9: The Organization Culture Focuses on Long Term Issues which make it Better to Perceive the Long Term Benefits of ICT and, therefore, this makes it More Favorable in Adoption of Donor Funded ICT

\begin{tabular}{|l|l|l|}
\hline & Frequency & percent \\
\hline The organization culture focuses strongly disagree & 2 & $3.0 \%$ \\
on long term issues which make it disagree & 5 & $7.5 \%$ \\
better to perceive the long term neutral & 7 & $10.4 \%$ \\
benefits of ICT and, therefore, this agree & 44 & $65.7 \%$ \\
makes it more favorable in strongly agree & 9 & $13.4 \%$ \\
adoption of donor funded ICT &
\end{tabular}

The respondents were asked if their organization culture is centralized, individuals at the organizational center exercise control and leadership and this has influenced the ICT adoption. A majority $(49.3 \%)$ of the respondents agreed while $19.4 \%$ strongly agreed bringing to a total of $(68.7 \%)$ of those who agreed. Eleven point nine percent were neutral and $11.9 \%$ disagreed and $7.5 \%$ strongly disagreed. The results are presented in table 10.

Table 10: Our organization culture is centralized, individuals at the organizational center exercise control and leadership and this has influenced the ICT adoption

\begin{tabular}{|l|l|l|}
\hline \multicolumn{2}{|c|}{ Frequency } & percent \\
\hline Our organization culture is strongly disagree & 5 & $7.5 \%$ \\
centralized, individuals at the Disagree & 8 & $11.9 \%$ \\
organizational center exercise Neutral & 8 & $11.9 \%$ \\
control and leadership and this has Agree & 33 & $49.3 \%$ \\
influenced the ICT adoption strongly agree & 13 & $19.4 \%$ \\
\hline
\end{tabular}

The respondents were asked if their organization is highly bureaucratic which makes it unsuitable as a vehicle for project implementation and ICT adoption. A majority $56.7 \%$ of the respondents agreed while $11.9 \%$ strongly agreed bringing to a total of $(68.6 \%)$ of those who agreed. Nineteen point four percent were neutral, $6 \%$ of the respondents disagreed and $6 \%$ of the respondents strongly disagreed. The results are presented in table 11 
Table 11 Our organization is highly bureaucratic which makes it unsuitable as a vehicle for project implementation and ICT adoption

\begin{tabular}{|l|l|l|}
\hline & Frequency & percent \\
\hline Our organization is highly Disagree $_{\text {ingly disagree }}$ & 4 & $6.0 \%$ \\
bureaucratic which makes it Neutral & 4 & $6.0 \%$ \\
unsuitable as a vehicle for project Agree & 13 & $19.4 \%$ \\
implementation and ICT adoption Atrongly agree & 38 & $56.7 \%$ \\
& 8 & $11.9 \%$ \\
\hline
\end{tabular}

The respondents were asked if their organization strives to achieve specific goal by using expertise and this has been a key factor in determining the adoption of ICT. A majority 55.2\% of the respondents agreed while $16.4 \%$ strongly agreed bringing to a total of $71.6 \%$ of those who agreed. Ten point four percent were neutral, $11.9 \%$ disagreed and $6 \%$ of the respondents strongly disagreed. The results are presented in table 12.

Table 12: Our Organization Strives to Achieve Specific Goal by using Expertise and this has been a Key factor in determining the Adoption of ICT

\begin{tabular}{|c|c|c|}
\hline & Frequency & percent \\
\hline $\begin{array}{ll}\text { Our organization strives to achieve } & \text { strongly disagree } \\
\text { disagree } \\
\text { specific goal by using expertise } & \text { neutral } \\
\text { and this has been a key factor in } & \text { agree } \\
\text { determining the adoption of ICT } & \text { strongly agree }\end{array}$ & $\begin{array}{l}4 \\
8 \\
7 \\
37 \\
11\end{array}$ & $\begin{array}{l}6.0 \% \\
11.9 \% \\
10.4 \% \\
55.2 \% \\
16.4 \%\end{array}$ \\
\hline
\end{tabular}

\subsubsection{Our Organization Public Sector Culture focuses on Political, Social and Economic} Issues which Influences Adoption of ICT

The respondents were asked if their organization public sector culture focuses on political, social and economic issues which influence adoption of ICT. A majority (43.3\%) agreed while $22.4 \%$ strongly agreed bringing to a total of $(65.7 \%)$ of those who agreed. Sixteen point four percent were neutral and $11.9 \%$ disagreed and $6 \%$ strongly disagreed. The results are presented in table 13

Table 13: Our Organization Public Sector Culture focuses on Political, Social and Economic Issues which Influences Adoption of ICT

\begin{tabular}{|c|c|c|}
\hline & Frequency & percent \\
\hline $\begin{array}{lll}\text { Our organization public sector } & \text { strongly disagree } \\
\text { culture focuses on political, social } & \text { Disagree } \\
\text { and economic issues which } & \text { Neutral } \\
\text { influences adoption of ICT } & \text { Agree } \\
\text { induree } & & \text { strongly agree }\end{array}$ & $\begin{array}{l}4 \\
8 \\
11 \\
29 \\
15\end{array}$ & $\begin{array}{l}6.0 \% \\
11.9 \% \\
16.4 \% \\
43.3 \% \\
22.4 \%\end{array}$ \\
\hline
\end{tabular}


The respondents were asked if Cultural factors such as the notion of time, power distance, the ability of the leader to consolidate his authority influences ICT adoption. A majority $53.7 \%$ of the respondents agreed while $16.4 \%$ strongly agreed bringing to a total of $(70.1 \%)$ of those who agreed. Fourteen point nine percent were neutral and $10.4 \%$ disagreed and $4.5 \%$ strongly disagreed. The results are presented in table 14.

Table 14 Cultural factors such as the Notion of Time, Power Distance, the Ability of the Leader to consolidate his Authority Influences ICT Adoption

\begin{tabular}{|l|l|l|}
\hline & Frequency & percent \\
\hline Cultural factors such as the notion strongly disagree & 3 & $4.5 \%$ \\
of time, power distance, the Disagree & 7 & $10.4 \%$ \\
ability of the leader to consolidate Neutral & 10 & $14.9 \%$ \\
his authority influences ICT Agree & 36 & $53.7 \%$ \\
adoption & 11 & $16.4 \%$ \\
\hline
\end{tabular}

Correlation results in table 15 indicates that the relationship between organizational culture and adoption of donor funded ICT projectis positive and significant $(\mathrm{r}=0.678, \mathrm{p}$ value $<0.000)$. The findings imply that organizational culture has significant effect on adoption of donor funded ICT project

Table 15: Correlations

\begin{tabular}{|ll|l|l|}
\hline & & Donor Funded & $\begin{array}{l}\text { Organizational } \\
\text { Culture }\end{array}$ \\
\hline \multirow{2}{*}{ Donor Funded } & Pearson Correlation & 1 & \\
& Sig. (2-tailed) & & \\
& N & 67 & \\
& Pearson Correlation & .678 & 1 \\
Organizational Culture & Sig. (2-tailed) & .000 & 67 \\
& N & 67 & 67 \\
\hline
\end{tabular}

\subsection{Infrastructural factors}

The respondents were asked if the organization has provided training opportunities and if this has influenced the ICT adoption. A majority $61.2 \%$ of the respondents agreed while $13.4 \%$ strongly agreed bringing to a total of $(74.6 \%)$ of those who agreed. Fourteen point nine percent were neutral and $7.5 \%$ disagreed while $3 \%$ strongly disagreed. The results are presented in table 16 
Journal of Entrepreneurship and Project Management

ISSN 2520 - 9116 (Online)

Vol. 2, Issue 1 No. 1, pp 1 - 19, 2016

Table 16: The Organization has provided Training Opportunities and this has influenced the ICT Adoption

\begin{tabular}{|c|c|c|}
\hline & Frequency & percent \\
\hline $\begin{array}{ll} & \text { strongly disagree } \\
\text { The organization has provided } & \text { Disagree } \\
\text { training opportunities and this has } & \text { Neutral } \\
\text { influenced the ICT adoption } & \text { Agree } \\
& \text { strongly agree }\end{array}$ & $\begin{array}{l}2 \\
5 \\
10 \\
41 \\
9\end{array}$ & $\begin{array}{l}3.0 \% \\
7.5 \% \\
14.9 \% \\
61.2 \% \\
13.4 \%\end{array}$ \\
\hline
\end{tabular}

The respondents were asked if the organization has provided business-specific advice and this has influenced the ICT adoption majority $50.7 \%$ of the respondents agreed while $23.9 \%$ strongly agreed bringing to a total of $(74.6 \%)$ of those who agreed. Nine percent $(9 \%)$ were neutral and $9 \%$ disagreed while $7.5 \%$ strongly disagreed. The results are presented in table 17.

Table 17: The Organization has provided Business-Specific Advice and this has influenced the ICT Adoption

\begin{tabular}{|c|c|c|}
\hline & Frequency & percent \\
\hline $\begin{array}{ll} & \text { strongly disagree } \\
\text { The organization has provided } & \text { Disagree } \\
\text { business-specific advice and this } & \text { Neutral } \\
\text { has influenced the ICT adoption } & \text { Agree } \\
& \text { strongly agree }\end{array}$ & $\begin{array}{l}5 \\
6 \\
6 \\
34 \\
16\end{array}$ & $\begin{array}{l}7.5 \% \\
9.0 \% \\
9.0 \% \\
50.7 \% \\
23.9 \%\end{array}$ \\
\hline
\end{tabular}

The respondents were asked if their organization culture is centralized, individuals at the organizational center exercise control and leadership and this has influenced the ICT adoption. A majority $49.3 \%$ of the respondents agreed while $19.4 \%$ strongly agreed bringing to a total of $(68.7 \%)$ of those who agreed. Eleven point nine percent were neutral and $11.9 \%$ disagreed while $7.5 \%$ strongly disagreed. The results are presented in table 18

Table 18: Our Organization Culture is centralized, Individuals at the Organizational Center Exercise control and Leadership and this has influenced the ICT Adoption

\begin{tabular}{|l|l|l|}
\hline & Frequency & percent \\
\hline Our organization culture is strongly disagree & 5 & $7.5 \%$ \\
centralized, individuals at the disagree & 8 & $11.9 \%$ \\
organizational center exercise Neutral & 8 & $11.9 \%$ \\
control and leadership and this has Agree & 33 & $49.3 \%$ \\
influenced the ICT adoption strongly agree & 13 & $19.4 \%$ \\
\hline
\end{tabular}

The respondents were asked if the organization has adequate expertise and if this has influenced the ICT adoption. A majority (49.3\%) agreed while $16.4 \%$ strongly agreed bringing to a total of 
Journal of Entrepreneurship and Project Management

ISSN 2520 - 9116 (Online)

Vol. 2, Issue 1 No. 1, pp 1 - 19, 2016

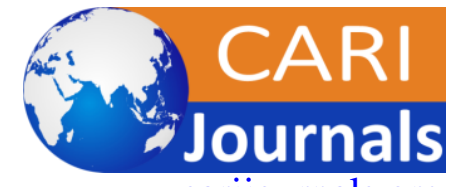

WwW.carijournals.org

$65.7 \%$ of those who agreed. Thirteen point four percent (13.4\%) were neutral and $13.4 \%$ disagreed while $7.5 \%$ strongly disagreed. The results are presented in table 19.

Table 19: The Organization has Adequate Expertise and this has influenced the ICT Adoption

\begin{tabular}{|c|c|c|}
\hline & Frequency & percent \\
\hline $\begin{array}{ll} & \text { strongly disagree } \\
\text { The organization has adequate } & \text { disagree } \\
\text { expertise and this has influenced } & \text { Neutral } \\
\text { the ICT adoption } & \text { Agree } \\
& \text { strongly agree }\end{array}$ & $\begin{array}{l}5 \\
9 \\
9 \\
33 \\
11\end{array}$ & $\begin{array}{l}7.5 \% \\
13.4 \% \\
13.4 \% \\
49.3 \% \\
16.4 \%\end{array}$ \\
\hline
\end{tabular}

The respondents were asked if the organization has adequate support staff for decision support system and if this has influenced the ICT adoption. A majority (62.7\%) agreed while $13.4 \%$ strongly agreed bringing to a total of $(76.1 \%)$ of those who agreed. Eleven point nine percent were neutral and $7.5 \%$ disagreed and $4.5 \%$ strongly disagreed. The results are presented in table 20

Table 20: The Organization has Adequate Support Staff for Decision Support System and this has influenced the ICT Adoption

\begin{tabular}{|c|c|c|}
\hline & Frequency & percent \\
\hline $\begin{array}{ll}\text { The organization has adequate } & \text { strongly disagree } \\
\text { support staff for decision support } & \text { Nisagree } \\
\text { system and this has influenced the } & \text { Agral } \\
\text { ICT adoption } & \text { Agree } \\
& \text { strongly agree }\end{array}$ & $\begin{array}{l}3 \\
5 \\
8 \\
42 \\
9\end{array}$ & $\begin{array}{l}4.5 \% \\
7.5 \% \\
11.9 \% \\
62.7 \% \\
13.4 \%\end{array}$ \\
\hline
\end{tabular}

The respondents were asked if there is adequate resources to roll out donor funded ICT projects. A majority (47.8\%) agreed while $28.4 \%$ strongly agreed bringing to a total of $(76.2 \%)$ of those who agreed. Six percent were neutral, $9 \%$ disagreed and $9 \%$ strongly disagreed. The results are presented in table 21

Table 21: There is Adequate Resources to Roll out Donor Funded ICT Projects

\begin{tabular}{|l|l|l|l|}
\hline \multicolumn{2}{|l|}{ Statement } & Frequency & percent \\
\hline \multirow{2}{*}{$\begin{array}{l}\text { There is adequate resources } \\
\text { to roll out donor funded ICT } \\
\text { projects }\end{array}$} & strongly disagree & 6 & $9.0 \%$ \\
\cline { 2 - 4 } & Disagree & 6 & $9.0 \%$ \\
\cline { 2 - 4 } & Neutral & 4 & $6.0 \%$ \\
\cline { 2 - 4 } & Agree & 32 & $47.8 \%$ \\
\cline { 2 - 4 } & strongly agree & 19 & $28.4 \%$ \\
\hline
\end{tabular}

Correlation results in table 22 indicates that the relationship between Infrastructural factor and adoption of donor funded ICT project is positive and significant $(r=0.268, p$ value $<0.028)$. The 
Journal of Entrepreneurship and Project Management

ISSN 2520 - 9116 (Online)

Vol. 2, Issue 1 No. 1, pp 1 - 19, 2016

findings imply that Infrastructural factor has significant effect on adoption of donor funded ICT project

Table 22: Correlations

\begin{tabular}{|ll|l|l|}
\hline & & $\begin{array}{l}\text { Infrastructural } \\
\text { Factor }\end{array}$ & Donor Funded \\
\hline \multirow{4}{*}{ Infrastructural Factor } & Pearson Correlation & 1 & \\
& Sig. (2-tailed) & & \\
& $\mathrm{N}$ & 67 \\
Dearson Correlation & .268 & 1 \\
& Sig. (2-tailed) & .028 & 67 \\
\hline
\end{tabular}

\subsection{Donor Funded ICT project}

The respondents were asked if the donor funding received for ICT projects has exceeded the budgetary provisions. A majority $58.2 \%$ of the respondent agreed while $14.9 \%$ strongly agreed bringing to a total of $(73.1 \%)$ of those who agreed. Eleven point nine percent were neutral and $11.9 \%$ disagreed while 3\% strongly disagreed. The results are presented in table 23.

Table 23: The Donor Funding Received for ICT Projects has exceeded the Budgetary Provisions

\begin{tabular}{|l|l|l|l|}
\hline \multicolumn{2}{|c|}{ strongly disagree } & Frequency & percent \\
\hline \multicolumn{2}{|c|}{ The donor funding received for disagree } & 2 & $3.0 \%$ \\
ICT projects has exceeded the neutral & 8 & $11.9 \%$ \\
budgetary provisions & 8 & $11.9 \%$ \\
\multicolumn{2}{|c|}{ agree } & 39 & $58.2 \%$ \\
& strongly agree & 10 & $14.9 \%$ \\
\hline
\end{tabular}

The respondents were asked if the donor funding to ICT has increased over the last five years. A majority $59.7 \%$ of the respondent agreed while $16.4 \%$ strongly agreed bringing to a total of (76.1\%) of those who agreed. Thirteen point four percent were neutral and $7.5 \%$ disagreed while $3 \%$ strongly disagreed. The results are presented in table 24

Table 24: The Donor Funding to ICT has increased over the last Five Years

\begin{tabular}{|c|c|c|c|}
\hline & & Frequency & percent \\
\hline \multirow{5}{*}{$\begin{array}{l}\text { The donor funding to ICT has } \\
\text { increased over the last five years }\end{array}$} & strongly disagree & 2 & $3.0 \%$ \\
\hline & Disagree & 5 & $7.5 \%$ \\
\hline & Neutral & 9 & $13.4 \%$ \\
\hline & Agree & 40 & $59.7 \%$ \\
\hline & strongly agree & 11 & $16.4 \%$ \\
\hline
\end{tabular}


The respondents were asked if their organization has invested in searching information about possible donor funding to ICT projects. A majority $49.3 \%$ of the respondent agreed while $23.9 \%$ strongly agreed bringing to a total of $(72.2 \%)$ of those who agreed. Fourteen point nine percent were neutral and $6 \%$ disagreed while $6 \%$ strongly disagreed. The results are presented in table 25

Table 25: Our organization has invested in Searching Information about Possible Donor Funding to ICT Projects

\begin{tabular}{|c|c|c|}
\hline & Frequency & percent \\
\hline $\begin{array}{lll} & & \\
\text { Our organization has invested in } & \text { Disagree } \\
\text { searching information about disagree } & \text { Neutral } \\
\text { possible donor funding to ICT } & \text { Agree } \\
\text { projects } & \text { strongly agree }\end{array}$ & $\begin{array}{l}4 \\
4 \\
10 \\
33 \\
16\end{array}$ & $\begin{array}{l}6.0 \% \\
6.0 \% \\
14.9 \% \\
49.3 \% \\
23.9 \%\end{array}$ \\
\hline
\end{tabular}

The respondents were asked if their organization has attracted more donors funding to ICT project compared to its peers. A majority $47.8 \%$ of the respondent agreed while $16.4 \%$ strongly agreed bringing to a total of $(64.2 \%)$ of those who agreed. Twenty three point nine percent were neutral and $7.5 \%$ disagreed while $4.5 \%$ strongly disagreed. The results are presented in table 26

Table 26: Our Organization has attracted more Donors Funding to ICT Project Compared to its Peers

\begin{tabular}{|c|c|c|}
\hline & Frequency & percent \\
\hline $\begin{array}{ll} & \text { strongly disagree } \\
\text { Our organization has attracted } & \text { Disagree } \\
\text { more donor funding to ICT project } & \text { Neutral } \\
\text { compared to its peers } & \text { Agree } \\
& \text { strongly agree }\end{array}$ & $\begin{array}{l}3 \\
5 \\
16 \\
32 \\
11\end{array}$ & $\begin{array}{l}4.5 \% \\
7.5 \% \\
23.9 \% \\
47.8 \% \\
16.4 \%\end{array}$ \\
\hline
\end{tabular}

The respondents were asked if their organization has attracted future donor commitments to ICT project funding. A majority 53.7\% of the respondent agreed while $16.4 \%$ strongly agreed bringing to a total of $(69.1 \%)$ of those who agreed. Thirteen point four percent were neutral and $10.4 \%$ disagreed while $6 \%$ strongly disagreed. The results are presented in table 27. 
Journal of Entrepreneurship and Project Management

ISSN 2520 - 9116 (Online)

Vol. 2, Issue 1 No. 1, pp 1 - 19, 2016

Table 27: Our organization has attracted future donor commitments to ICT project funding

\begin{tabular}{|ll|l|l|}
\hline & & Frequency & percent \\
\hline & strongly disagree & 4 & $6.0 \%$ \\
Our organization has attracted Disagree & 7 & $10.4 \%$ \\
future donor commitments to ICT Neutral & 9 & $13.4 \%$ \\
project funding & 36 & $53.7 \%$ \\
\multicolumn{2}{|r|}{ Agree } & 11 & $16.4 \%$ \\
\hline
\end{tabular}

\subsection{DISCUSSION CONCLUSIONS AND RECOMMENDATIONS}

\subsection{Findings}

One of the objectives of the study was to determine the technological factors that influence the adoption of donor funded ICT projects in public sectors. Results indicated that majority of the respondents agreed with the statements that perceived usefulness is a key factor influencing adoption of donor funded ICT projects, perceived ease of use is a key factor influencing adoption of donor funded ICT projects, reduction in operational costs is a key factor influencing adoption of donor funded ICT projects, improvement in revenues is a key factor influencing adoption of donor funded ICT projects, increased customer outreach is a key factor influencing adoption of donor funded ICT projects and Customer satisfaction is a key factor influencing adoption of donor funded ICT project. The relationship between technological factor and adoption of donor funded ICT projects is positive and significant $(\mathrm{r}=0.795$, $\mathrm{p}$ value $<0.000)$. The findings imply that technological factor has significant effect on adoption of donor funded ICT projects.

The study also sought to determine the influence of culture on the adoption of donor funded ICT project in public sectors. Results indicated that majority of the respondents agreed with the statements the organization cultures is focused on the short term, therefore, the organization expects quick results and this has influenced ICT adoption, the organization culture focuses on long term issues which make it better to perceive the long term benefits of ICT and, therefore, this makes it more favorable in adoption of donor funded ICT, Our organization culture is centralized, individuals at the organizational center exercise control and leadership and this has influenced the ICT adoption, our organization is highly bureaucratic which makes it unsuitable as a vehicle for project implementation and ICT adoption, our organization strives to achieve specific goal by using expertise and this has been a key factor in determining the adoption of ICT, our organization public sector culture focuses on political, social and economic issues which influences adoption of ICT and cultural factors such as the notion of time, power distance, the ability of the leader to consolidate his authority influences ICT adoption. The relationship between organizational culture and adoption of donor funded ICT projects is positive and significant $(\mathrm{r}=0.678, \mathrm{p}$ value $<0.000)$. The findings imply that organizational culture has significant effect on adoption of donor funded ICT projects.

The study attempted to determine the infrastructural factors that influence the adoption of donor funded ICT project in public sectors. Results indicated that majority of the respondents agreed 
with the statements that the organization has provided training opportunities and this has influenced the ICT adoption, the organization has provided business-specific advice and this has influenced the ICT adoption, the organization top management actively participates in the affairs of the company and this has influenced the ICT adoption, the organization has adequate expertise and this has influenced the ICT adoption and the organization has adequate support staff for decision support system and this has influenced the ICT adoption. The relationship between Infrastructural factor and adoption of donor funded ICT projects is positive and significant $(\mathrm{r}=0.268, \mathrm{p}$ value $<0.028)$. The findings imply that Infrastructural factor has significant effect on adoption of donor funded ICT projects.

\subsection{Conclusions}

Following the study results, it was possible to conclude that Technological factors were highly emphasized in the adoption of donor funded ICT project in public sectors. The other objective of the study was to determine the influence of culture on the adoption of donor funded ICT project in public sectors. Following the study results, it was possible to conclude that culture was highly emphasized on the adoption of donor funded ICT project in public sectors. The other objective of the study was to determine the infrastructural factors that influence the adoption of donor funded ICT project in public sectors. Following the study results, it was possible to conclude that infrastructural factors were highly emphasized the adoption of donor funded ICT project in public sectors.

\subsection{Recommendations}

Following study results, it is recommended that government should consider implementing a robust public sector policy that aims at enhancing ICT use, the development of donor funded ICT project and making ICT hardware and software accessible and affordable to majority of individual and firms. The study also recommends that organization culture should be centralized, individuals at the organizational center should exercise control and leadership. The study also recommends that organizations are highly bureaucratic which makes it unsuitable as a vehicle for project implementation and ICT adoption. In addition the study recommends that organization should strive to achieve specific goal by using expertise which is a key factor in determining the adoption of ICT.

\subsection{Suggestions for Further Studies}

The study recommends that further investigation be done on the factors that are affecting adoption of donor funded ICT projects in the private sector. The study also recommends that investigation should be done on the impact of trust and perceived risk on internet banking adoption in Kenya by looking at an extension of technology acceptance model. The study also recommends that another study should be done on the effect of innovation characteristics on mobile services (banking and money transfer) adoption intention and noted that compatibility is the perception of innovation as being consistent with the existing values, past experiences, and needs of potential adopter. 


\section{REFERENCES}

Castillo, E. (2009), Process Optimization: A Statistical Approach, NY: Springer (International Series in Operations Research and Management Science), July 2007. (Reviewed in: Journal of Quality Technology, 40, 2, 2009)

Davis, D. (1989). Perceived usefulness, perceived ease of use, and user acceptance of information technology. MIS Quarterly, 13(3), 319-340.

Ghaladari, K. (2012). The Effect of Performance Expectancy, Effort Expectancy, Social Influence and Facilitating Conditions on Acceptance of E-Banking Services in Iran: the Moderating Role of Age and Gender Middle-East Journal of Scientific Research 12 (6): 801-807.

Heeks, R. (2004). Last update, Building Transparency, Fighting Corruption with ICTs [Homepage of iConnect Online], [Online]. Available: http://www.iconnectonline.org/base/ic_show_news?sc=118\&id=236.

Heeks, R., \& Davies, A., (2000). Different Approaches to Information Age Reform. In: R. HEEKS, Reinventing Government in the information age. London and New York: Rout ledge, pp. 22-48.

Limo, A. (2003)-last update, Computer use bound to transform Kenya [Homepage of Nation Media Group], [Online]. Available http://www.nationaudio.com/News/DailyNation/24122003/Comment/Comment24122003 1.html [10.01. 2004].

Ndou, V. (2004). E-Government for developing countries: Opportunities and Challenges. http://www.is.cityu.edu.hk/research/ejisdc/voll8/v18rl.pdf edn. City University of Hong Kong: City University of Hong Kong, Erasmus University of Rotterdam and University of Nebraska at Omaha 